\title{
PERFORMA PERTUMBUHAN DAN KELANGSUNGAN HIDUP KEPITING BAKAU (Scylla sp.) DENGAN PEMBERIAN KOMBINASI PAKAN KEONG MAS DAN IKAN RUCAH
}

\section{GROWTH PERFOMANCE AND SURVIVAL OF MUD CRAB (Scylla sp.) FEEDING WITH COMBINATION OF GOLDEN SNAIL AND TRASH FISHES}

\section{La Ode Muhammad Harisud, Endang Bidayani dan Ahmad Fahrul Syarif*}

\author{
Jurusan Akuakultur, Universitas Bangka Belitung \\ Kampus Terpadu UBB, Gedung Teladan, Desa Balunijuk, Kepulauan Bangka Belitung, 33172 Indonesia \\ Email: ahmadfahrulsyarif@gmail.com
}

\begin{abstract}
ABSTRAK
Kepiting bakau (Scylla sp.) merupakan salah satu komoditas yang memiliki nilai ekonomis tinggi dan potensial untuk dibudidayakan. Penelitian ini bertujuan untuk mengevaluasi performa pertumbuhan kepiting bakau dengan pemberian kombinasi pakan keong mas dan ikan rucah. Materi uji yang digunakan adalah kepiting bakau dengan bobot rata-rata 111,16 gram sebanyak 36 ekor. Metode yang digunakan dalam penelitian ini adalah metode eksperimental dengan menggunakan Rancangan Acak Lengkap (RAL). Perlakuan yang diberikan berupa pakan keong mas, kombinasi keong mas dan ikan rucah serta pemberian pakan ikan rucah. Hasil penelitian menunjukan bahwa pemberian pakan kombinasi tidak berpengaruh nyata terhadap pertumbuhan dan kelulushidupan kepiting bakau. Bobot mutlak pada

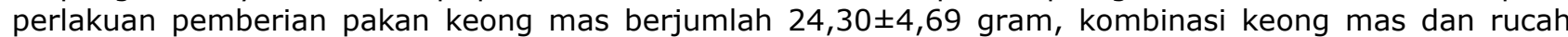

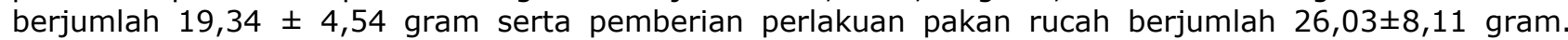
Panjang mutlak pada perlakuan pemberian pakan keong mas berjumlah 0,26 $\pm 0,08 \mathrm{~cm}$, kombinasi keong mas dan rucah berjumlah $0,24 \pm 0,05 \mathrm{~cm}$ serta pemberian perlakuan pakan rucah berjumlah $0,36 \pm 0,11$ $\mathrm{cm}$. Persentase kelulushidupan rata-rata adalah $83,33 \%$ pada semua perlakuan.
\end{abstract}

Kata kunci : Kepiting Bakau, Scylla sp., Keong Mas, Ikan Rucah, Performa Pertumbuhan

\begin{abstract}
Mud crab (Scylla sp.) is the one of the commodities that have high economic value and potential to be cultivated. This research aimed to evaluate the growth performance of mud crab feeding with combinations of golden snail and trash fishes. The test material used was mud crab with an average weight of 111.16 grams as number of 36 individuals. The method used in this research was experimental method using a Completely Randomized Design (CRD). The treatment was golden snail as a feed, a combination of golden snail and trash fishes and trash fishes as feed. The results showed that combination feeding did not significantly affect of the growth and survival of mud crabs. The absolute weight in the treatment of golden snail feed was $24.30 \pm 4.69$ grams, the combination of golden snail and trash fishes was $19.34 \pm 4.54 \mathrm{grams}$ and the treatment of trash fishes as feed was $26.03 \pm 8.11 \mathrm{grams}$. The absolute length of the treatment of golden snail feeding was $0.26 \pm 0.08 \mathrm{~cm}$, the combination of golden snail and trash fishes was $0.24 \pm 0.05 \mathrm{~cm}$ and the treatment of trash fishes as feed was $0.36 \pm 0.11 \mathrm{~cm}$. The avrages percentage of survival for each treatment was $83.33 \%$.
\end{abstract}

Keywords : Mud Crab, Scylla sp., Golden Snail, Trash Fishes, Grwoth Performance

\section{PENDAHULUAN}

Indonesia memiliki wilayah perairan payau laut yang luas dan berpotensi untuk dimanfaatkan dalam kegiatan budidaya komoditas perikanan yang bernilai ekonomis tinggi. Kepiting bakau (Scylla sp.) merupakan salah satu komoditas yang memiliki nilai ekonomis tinggi dan potensial untuk dibudidayakan. Jumlah permintaan pasar lokal maupun internasional terhadap kepiting bakau dari tahun ke tahun semakin meningkat. Berdasarkan data yang diperoleh dari United Nations Commodity Trade tahun 2012, ekspor kepiting dari Indonesia berjumlah $7.267 .042 \mathrm{~kg}$ pada tahun 2001 meningkat menjadi $9.346 .589 \mathrm{~kg}$ pada tahun 2010. 
Kepiting bakau juga disukai karena rasa dagingnya yang enak dan memiliki gizi yang tinggi serta baik untuk pemenuhan kebutuhan protein. Daging kepiting bakau mengandung $47,5 \%$ protein dan $11,20 \%$ lemak (Karim, 2008). Harga kepiting bakau di pasaran mencapai Rp $170.000 / \mathrm{kg}$, oleh karena itu perlu dilakukan kegiatan budidaya. Budidaya kepiting bakau sendiri dipengaruhi oleh beberapa faktor, salah satunya adalah pakan yang digunakan.

Jenis pakan yang digunakan dalam usaha budidaya kepiting bakau dapat berupa pakan alami dan pakan buatan. Ikan rucah merupakan salah satu jenis pakan alami atau pakan segar yang umumnya digunakan dalam budidaya kepiting. Ikan rucah dianggap dapat menghasilkan pertumbuhan yang lebih baik jika dibandingkan dengan pakan buatan. Hal ini dikarenakan jumlah ikan rucah masih melimpah, memiliki bau yang dapat memicu kepiting bakau untuk makan serta memiliki kandungan protein yang baik. Menurut Asyari \& Muflikhah (2005), ikan rucah memiliki kandungan nutrisi dengan protein $28,26 \%$, lemak $1,49 \%$, karbohidrat $1,76 \%$, abu $4,82 \%$, serat $4,10 \%$ dan kandungan air sebesar $59,57 \%$.

Budidaya kepiting bakau dengan pakan ikan rucah ternyata memiliki kendala walaupun jumlahnya melimpah, salah satunya adalah ketersediaan ikan rucah. Ikan rucah dengan ketersediannya ini masih dipengaruhi oleh musim dalam proses penangkapannya serta tidak setiap saat ikan rucah mudah untuk ditemukan. Solusi kendala tersebut tentu harus ditemukan, salah satu solusi yang ditawarkan peneliti adalah mengkombinasikan pakan berbahan dasar keong mas dan ikan rucah dalam kegiatan budidaya kepiting bakau.

Keong mas (Pomacea canaliculata) adalah jenis keong air tawar introduksi dari suku Ampullariidae yang masuk ke Indonesia di awal tahun 1980. Ketersediaan keong mas yang sangat melimpah disebabkan tingkat reproduksi yang tinggi serta kemampuannya dalam beradaptasi terhadap kondisi lingkungan yang kering atau estivasi (Marwoto, 1997). Keong mas mengandung 83 kalori makanan dengan protein $14,72 \%$, lemak $0,48 \%$, karbohidrat $7,95 \%$ dan kandungan lainnya (abu, serat dan air) sebesar 76,85\% (Sadinar et al., 2013).

Penelitian tentang pemberian pakan kombinasi untuk kepiting bakau pernah dilakukan oleh Idha et al. (2013) menggunakan kombinasi keong macan dengan ikan rucah. Sadinar et al. (2013) juga pernah melakukan penelitian tentang pengaruh perbedaan dosis pakan keong mas dan ikan rucah pada kepiting bakau (Scylla paramamosain). Hal inilah yang menyebabkan perlu dilakukan penelitian tentang performa pertumbuhan dan kelangsungan hidup kepiting bakau dengan pemberian kombinasi pakan keong mas dan ikan rucah.

\section{METODE PENELITIAN}

Penelitian ini menggunakan kepiting bakau berjumlah 36 ekor dengan kisaran berat rata-rata $111,16 \mathrm{gr}$. Kepiting bakau diperoleh dari pengepul kepiting bakau Desa Pagarawan, Kecamatan Merawang, Kabupaten Bangka. Pakan yang digunakan adalah keong mas dan ikan rucah.

Penelitian ini menggunakan Rancangan Acak Lengkap (RAL), terdiri dari 3 perlakuan dan 3 ulangan sehingga diperoleh 9 unit percobaan. Perlakuan pada penelitian ini menggunakan kombinasi pemberian pakan keong mas dan ikan rucah pada perlakuan. Rincian perlakuan adalah sebagai berikut:

a) Perlakuan $A$ : Pemberian pakan keong mas $100 \%(P A)$

b) Perlakuan B : Pemberian pakan kombinasi keong mas $50 \%$, ikan rucah $50 \%$ (PB)

C) Perlakuan $\mathrm{C}$ : Pemberian pakan ikan rucah $100 \%$ (PC)

Prosedur penelitian yang di lakukan di mulai dengan persiapan Wadah yang digunakan dalam penelitian ini adalah bak plastik bening berbentuk persegi panjang dengan ukuran panjang $30 \mathrm{~cm}$, lebar $30 \mathrm{~cm}$ dan tinggi $30 \mathrm{~cm}$ berjumlah 36 buah dengan ketinggian air $13 \mathrm{~cm}$. Setiap bak diisi 1 ekor kepiting bakau, setiap perlakuan dan ulangan masing-masing dibutuhkan 4 buah bak yang disusun menjadi satu rangkaian.

Kepiting bakau yang diperoleh dari pengepul diaklimatisasi di wadah pemeliharaan selama satu minggu. Kepiting bakau diberi pakan ikan rucah selama proses aklimatisasi yang bertujuan mengurangi stres pasca pengangkutan serta menyeragamkan jenis pakan sebelum penelitian dimulai. Pengangkutan kepiting bakau dilakukan dengan menggunakan karung yang diberi kain basah. Hal ini bertujuan untuk menjaga kelembapan dan mengurangi gesekan antar kepiting selama pengangkutan.

Penebaran dilakukan setelah proses aklimatisasi. Kepiting bakau yang akan ditebar terlebih dahulu ditimbang dan diukur lebar karapasnya menggunakan timbangan digital dan penggaris. Hal ini bertujuan untuk 
mengetahui berat dan lebar karapas kepiting bakau sebelum penebaran. Kepiting bakau diberi pakan dua kali sehari selama penelitian yakni pada pukul 08.00 dan pukul 16.00 WIB. Pakan yang digunakan adalah keong mas, ikan rucah dan kombinasi keduanya. Pemberian pakan dengan metode at satiation. Pakan ikan rucah yang akan digunakan terlebih dahulu dibersihkan dan dicuci menggunakan air bersih sedangkan untuk keong mas terlebih dahulu dipisahkan daging dan cangkang keong mas, kemudian dicuci menggunakan air garam untuk menghilangkan lendir dari keong mas, setelah itu dicuci kembali menggunakan air bersih mengalir. Untuk pemberian pakan kombinasi, jumlah pakan dibagi dengan persentase 50\% ikan rucah, 50\% daging keong mas.

\section{Kelulushidupan (Surival Rates)}

Kelulushidupan dihitung dengan menggunakan rumus Effendie (1997), yaitu :

$$
\text { Kelulushidupan }=\frac{N t}{N o} \times 100 \%
$$

Keterangan : Nt $=$ Jumlah Di Akhir Pemeliharaan; No = Jumlah Awal Pemeliharaan

\section{Pertumbuhan Bobot Mutlak}

Pertumbuhan bobot harian dihitung dengan menggunakan rumus Effendie (1997), yaitu :

Pertumbuhan Bobot Mutlak $=(\overline{\mathrm{W}} \mathrm{t}-\overline{\mathrm{W}} 0)$

Keterangan : $\overline{\mathrm{Wt}}=$ Bobot rata-rata pada waktu $\mathrm{t}(\mathrm{g}) ; \overline{\mathrm{W0}}=$ Bobot rata-rata pada awal percobaan $(\mathrm{g})$

\section{Pertambahan Lebar Karapas Mutlak}

Pertumbuhan lebar karapas mutlak dihitung menggunakan pertumbuhan nisbi dengan rumus Effendie (1997), yaitu :

Pertambahan Lebar Karapas Mutlak $=\overline{\mathrm{L}} \mathrm{t}-\overline{\mathrm{L}} 0$ Keterangan:L̄t = Lebar Karapas rata-rata kepiting pada waktu $\mathrm{t}(\mathrm{cm}) ; \overline{\mathrm{L}} 0=$ Lebar Karapas rata-rata kepiting pada awal percobaan $(\mathrm{cm})$

\section{Laju Pertumbuhan Spesifik ( $\alpha$ )}

Laju pertumbuhan harian dihitung dengan menggunakan rumus Huisman (1987), yaitu :

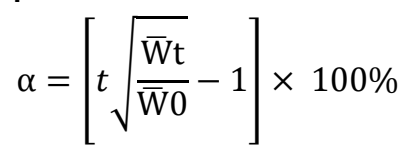

Keterangan: $\alpha=$ Laju pertumbuhan spesifik $(\%) ; \overline{\mathrm{W}} \mathrm{t}=$ Bobot pada waktu $\mathrm{t}(\mathrm{g}) ; \overline{\mathrm{Wo}}=$ Bobot rata-rata pada awal percobaan $(g)$; = Lama percobaan (hari)

\section{Efisiensi Pemanfaatan Pakan (EPP)}

Efisiensi pemanfaatan pakan dihitung dengan menggunakan rumus Tacon (1987), yaitu :

Efisiensi Pemanfaatan Pakan $=\frac{\mathrm{Bt}-\mathrm{B} 0}{\mathrm{~Pa}} \times 100 \%$ Keterangan: $\mathrm{Bt}=$ Biomassa pada waktu $\mathrm{t}$ (gram); Bo = Biomassa pada awal pemeliharaan (gram); $\mathrm{Pa}=$ Jumlah pakan yang diberikan selama pemeliharaan (gram)

\section{Analisis Kualitas Air}

Parameter kualitas air yang diamati dalam penelitian ini adalah suhu, salinitas, $\mathrm{pH}$, DO dan amonia. Suhu diukur setiap hari pada pagi dan sore hari, salinitas diukur dua hari sekali, pH dan DO (Dissolved Oxygen) dilakukan dua minggu sekali serta amonia diukur pada awal dan akhir penelitian.

\section{Analisis Data}

Analisis data yang digunakan adalah analisis sidik ragam pada taraf nyata 0,05. Apabila perlakuan pemberian kombinasi pakan berpengaruh nyata terhadap performa pertumbuhan dan kelulushidupan kepiting bakau, maka dilakukan uji lajut Beda Nyata Jujur (BNJ) untuk mengetahui perlakuan terbaik diantara taraf yang diuji. Parameter kualitas air sebagai pendukung, dipaparkan secara deskriptif dan disajikan dalam bentuk tabel.

\section{HASIL DAN PEMBAHASAN}

Data hasil kelulushidupan dari penelitian ini diperoleh dengan cara menghitung jumlah Kepiting Bakau pada hari ke-0 dan jumlah kepiting bakau yang hidup pada hari ke-56. Data derajat kelangsungan hidup ini diuji menggunakan ANOVA dengan taraf kepercayaan $\mathrm{P}>0,05$ dan menunjukan hasil bahwa pemberian pakan kombinasi tidak berpengaruh nyata pada tiap perlakuannya yaitu sebesar $83,33 \%$ (Gambar 1.)

Derajat kelangsungan hidup dapat dipengaruhi oleh beberapa faktor, khususnya faktor biotik dan abiotik. Faktor biotik meliputi kompetisi dalam mendapatkan makanan, predasi, parasit, kepadatan, umur, kemampuan beradaptasi dengan lingkungan 
serta proses penanganan sedangkan faktor abiotik meliputi kualitas air (Winestri et al 2014). Parameter kualitas air secara lengkap tersaji pada Tabel 1 . Salah satu penyebab kematian kepiting bakau adalah kegagalan molting. Proses molting pada kepiting bakau memerlukan energi yang cukup dari pakan yang diberikan serta kondisi lingkungan yang dibutuhkan. Menurut Warner (1997) molting pada kepiting bakau terdiri dari premolt, ekdisis, molting, postmolt dan intermolt.

Fase kritis kegagalan pada saat proses molting pada penelitian ini diduga terletak pada fase ekdisis. Hal ini dikarenakan pada fase ekdisis, kepiting bakau melepas eksoskeleton tua bersamaan dengan proses penyerapan air diperbanyak (Karim, 2005). Proses ini memerlukan energi yang besar dan lingkungan yang baik, pada fase ini tingkat sensitifitas kepiting bakau sangat rentan terhadap kegagalan molting. Tingkat sensitifitas yang tinggi disebabkan oleh beberapa hal, yaitu tidak adanya proses makan pada saat molting, proses osmoregulasi meningkat yang disebabkan proses penyerapan air dari lingkungan diperbanyak serta penggunaan energi baik energi protein maupun non protein digunakan untuk proses molting.

Pertambahan bobot mutlak kepiting bakau ini diperoleh dalam durasi penelitian selama 56 hari. Data pertambahan bobot mutlak ini diuji menggunakan ANOVA dengan taraf kepercayaan $\mathrm{P}>$ 0,05 dan menunjukan hasil bahwa pemberian pakan kombinasi tidak berpengaruh nyata pada tiap perlakuannya dengan nilai antara 19,3426,03 g (Gambar 2).

Hasil penelitian menunjukan bahwa penggunaan pakan kombinasi dan penggunaan pakan keong mas tidak memberikan perbedaan yang signifikan

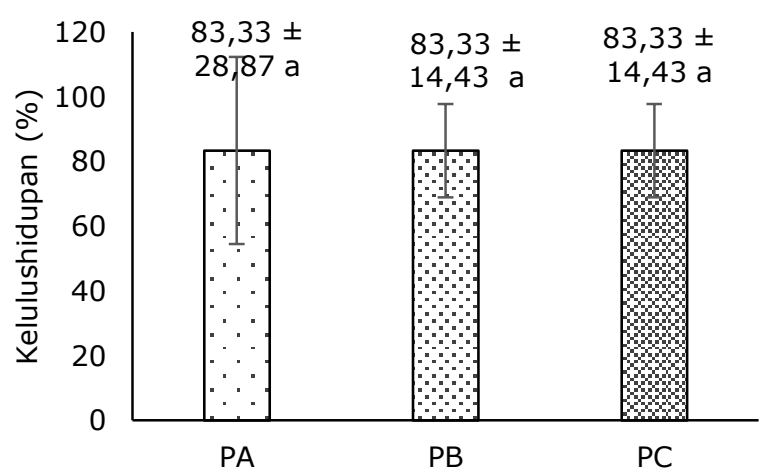

Keterangan : Huruf superscript yang sama menunjukkan pengaruh yang tidak berbeda nyata $(P>0,05)$

$\mathrm{PA}=$ pakan keong mas, $\mathrm{PB}=$ pakan kombinasi, $\mathrm{PC}=$ pakan ikan rucah

Gambar 1. Kelulushidupan Kepiting Bakau selama pemeliharaan dengan pakan ikan rucah terhadap pertambahan bobot mutlak. Persentase karbohidrat yang tinggi pada pakan keong mas diduga menjadi penyebab tidak adanya perbedaan yang signifikan dari jenis pakan yang diujikan terhadap pertambahan bobot mutlak. Yasin (2011) menyebutkan bahwa hewan kelas crustesea memerlukan karbohidrat dalam jumlah yang relatif lebih banyak. Hal ini disebabkan proses pembentukan khitin cangkang keras pada hewan kelas crustesea dan proses osmoregulasi memerlukan karbohidrat.

$$
\text { Asyari \& Muflikhah (2005) }
$$

menyebutkan, ikan rucah memiliki karbohidrat sebesar $1,76 \%$ dan kandungan karbohidrat pada keong mas sebesar 7,95\% dari 83 gram kalori. Karbohidrat berperan sebagai prekursor dalam proses metabolisme internal yang produknya dibutuhkan untuk pertumbuhan, contohnya asam amino non esensial dan asam nukleat. Hadadi (2002) menyatakan bahwa semakin tinggi karbohidrat pakan, konsumsi lemak cenderung menurun. Hal ini disebabkan karena karbohidrat selain sebagai sumber energi, juga dapat dikonversi menjadi lemak tubuh.

Kandungan nutrisi dalam setiap jenis pakan dan penggunaannya tentu berbedabeda, terutama penggunaan protein. Pakan yang digunakan dalam penelitian ini memiliki kandungan protein yang berbeda, hal ini menyebabkan adanya perbedaan jumlah protein dalam proses metabolisme di dalam tubuh. Penggunaan protein maksimum untuk pertumbuhan berhubungan erat dengan pemasukan protein dan ketersediaan energi nonprotein. Tinggi rendahnya pemasukan energi nonprotein berpengaruh terhadap penghematan penggunaan protein dalam

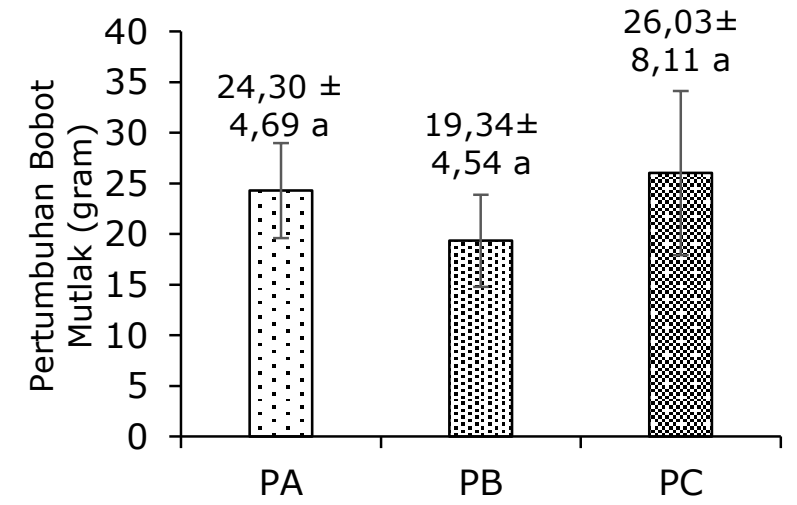

Keterangan : Huruf superscript yang sama menunjukkan pengaruh yang tidak berbeda nyata $(P>0,05)$

$\mathrm{PA}=$ pakan keong mas, $\mathrm{PB}=$ pakan kombinasi, $\mathrm{PC}=$ pakan ikan rucah

Gambar 2. Pertambahan bobot mutlak Kepiting Bakau selama pemeliharaan 
proses metabolisme. Energi nonprotein yang seimbang dengan protein yang masuk akan meningkatkan pemanfaatan protein untuk pertumbuhan (Karim, 2005).

Kepiting bakau membutuhkan pakan yang baik untuk mempertahankan eksistensi. Pertumbuhan kepiting bakau akan maksimal jika pakan yang diberikan mengandung semua unsur nutrien yang dibutuhkan. Karim (2005) menyatakan bahwa komposisi nutrisi pakan esensial akan menentukan pertumbuhan dan efesiensi pemanfaatan pakan itu sendiri. Kepiting bakau secara umum memerlukan nutrien berupa protein, karbohidrat, lemak, vitamin dan mineral.

Pertambahan panjang mutlak dari penelitian ini diperoleh dengan cara mengukur panjang karapas mutlak Kepiting Bakau selama penelitian. Data pertambahan panjang mutlak ini diuji menggunakan ANOVA dengan taraf kepercayaan $\mathrm{P}>0,05$ dan menunjukan hasil bahwa pemberian pakan kombinasi tidak berpengaruh nyata pada tiap perlakuannya yaitu sebesar0,240,36 cm (Gambar 3).

Pertambahan panjang mutlak berkaitan dengan pertambahan bobot mutlak dan proses ganti kulit (molting). Berdasarkan hasil penelitian yang disajikan dalam bentuk diagram pada Gambar 4, diduga bahwa kandungan karbohidrat dalam pakan ikan rucah tidak mencukupi jumlah kalori yang dibutuhkan dalam proses molting. Salah satu fungsi karbohidrat adalah pembentuk zat khitin dalam pengerasan cangkang.

Pakan dengan kandungan protein yang tinggi, belum tentu dapat mempercepat pertumbuhan apabila kandungan energi non proteinnya rendah. Energi protein yang

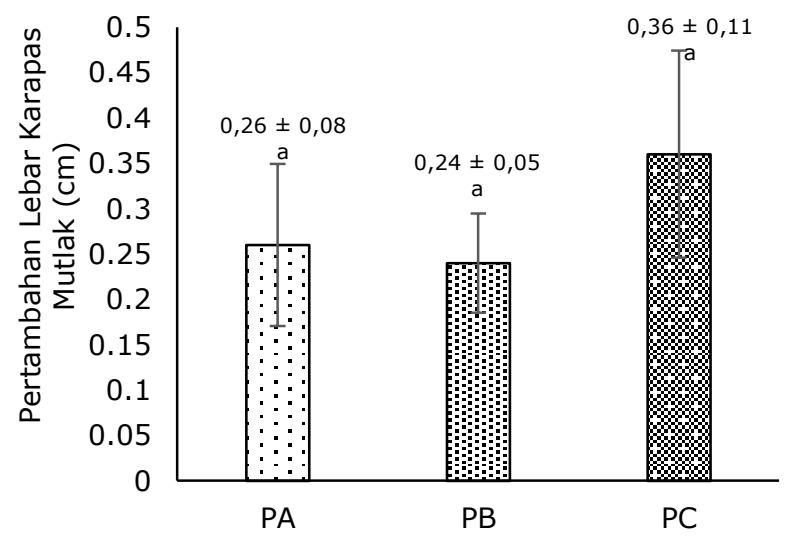

Keterangan : Huruf superscript yang sama menunjukkan pengaruh yang tidak berbeda nyata $(P>0,05)$

$\mathrm{PA}=$ pakan keong mas, $\mathrm{PB}=$ pakan kombinasi, $\mathrm{PC}=$ pakan ikan rucah

Gambar 3. Pertambahan lebar karapas mutlak Kepiting Bakau selama pemeliharaan digunakan untuk pertumbuhan terlebih dahulu digunakan untuk pemeliharaan dan aktivitas tubuh, sisa dari energi protein tersebut barulah digunakan untuk pertumbuhan (Karim, 2005). Hal inilah yang menjadi alasan perlunya energi non protein, salah satunya adalah karbohidrat. Salah satu fungsi karbohidrat yang lainnya adalah sebagai pengikat protein dan lipid yang merupakan jaringan antigen pada membran sel dan sekresi protein. Karbohidrat juga berperan dalam menghemat penggunaan protein sebagai sumber energi utama sehingga sumber energi protein dapat disimpan dalam bentuk daging biomasa, untuk kemudian digunakan dalam proses molting.

Pertambahan panjang mutlak terlihat jika telah terjadi proses molting, pada proses inilah jumlah karbohidrat sederhana dalam bentuk glikogen dan turunannya dalam bentuk lipid dibutuhkan dalam jumlah yang relatif banyak terutama dalam pembentukan zat khitin untuk proses pengerasan cangkang pascamolting serta memaksimalkan proses protein sparing effect. Protein sparing effect merupakan proses penghematan dan peningkatan pemanfaatan protein untuk pertumbuhan oleh energi non protein (Karim, 2005). Berdasarkan hal ini penggunaan pakan ikan rucah tidak berbeda secara signifikan hasilnya jika dibandingkan dengan pakan keong mas dan pakan kombinasinya terhadap pertambahan panjang mutlak kepiting bakau.

Data laju pertumbuhan spesifik dari penelitian ini diperoleh dengan cara menghitung jumlah pertambahan berat kepiting bakau selama penelitian lalu dibagi dengan lama pemeliharaan. Data LPS diuji menggunakan ANOVA dengan taraf kepercayaan $\mathrm{P}>0,05$ dan menunjukan hasil bahwa pemberian pakan kombinasi tidak berpengaruh nyata pada tiap perlakuannya yaitu sebesar 0,27-0,36\% (Gambar 4).

Persentase laju pertumbuhan spesifik yang kecil pada hasil penelitian diduga adanya pengaruh dari bobot kepiting pada awal penelitian. Hasil laju pertumbuhan spesifik pada penelitian ini jauh lebih kecil jika dibandingkan dengan penelitian Alamsyah dan Fujaya (2011) yang menjelaskan laju pertumbuhan spesifik sebesar 2,75\% dengan rata-rata bobot awal penelitian sebesar 56 gram. Pada penelitian ini, kepiting bakau yang digunakan berukuran 111,16 gram dengan hasil persentase tertinggi pada perlakuan pemberian pakan ikan rucah sebesar 0,36\%. Kepiting yang 


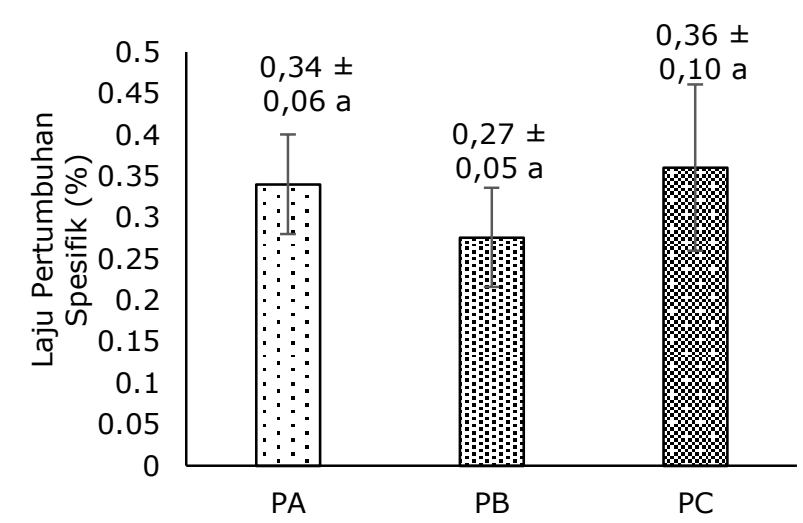

Keterangan : Huruf superscript yang sama menunjukkan pengaruh yang tidak berbeda nyata $(P>0,05)$

$\mathrm{PA}=$ pakan keong mas, $\mathrm{PB}=$ pakan kombinasi, $\mathrm{PC}=$ pakan ikan rucah

Gambar 4. Laju pertumbuhan spesifik Kepiting Bakau selama
pemeliharaan

masih dalam stadia muda berganti kulit lebih sering, hal inilah yang menyebabkan kepiting muda lebih cepat tumbuh jika dibandingkan dengan kepiting dewasa. Warner (1997) juga menyatakan bahwa pada saat kepiting masih kecil penambahan bobot dapat mencapai $400 \%$ setelah terjadi proses molting.

Menurut Tacon (1987), pada kondisi energi pakan yang tidak cukup, kultivan akan memanfaatkan protein dalam tubuh untuk menjaga kebutuhan akan energi. Hal ini akan menyebabkan keterlambatan untuk tumbuh hingga terjadinya penurunan berat tubuh kultivan. Pertumbuhan yang maksimal dapat terjadi apabila energi yang disimpan lebih besar dibandingkan dengan energi yang digunakan untuk aktifitas tubuh. Tinggi rendahnya laju pertumbuhan spesifik juga berkaitan dengan pemanfaatan pakan oleh kultivan, dimana semakin tinggi pemanfaatan pakan oleh kultivan maka akan semakin tinggi pula nilai persentase laju pertumbuhan spesifik (Karim, 2005).

Tingkat konsumsi pakan juga dapat mempengaruhi pertumbuhan, dimana kualitas dan kuantitas pakan yang dikonsumsi akan menentukan proses metabolisme dalam tubuh kultivan, jumlah energi yang disimpan dalam tubuh, jumlah energi yang digunakan untuk keperluan aktivitas tubuh serta menentukan kemampuan tubuh kultivan dalam memanfaatkan kandungan nutrisi yang didapatkan dari pakan yang dikonsumsi (Tacon, 1987).

Efesiensi pemanfaatan pakan (EPP) didapatkan dari jumlah pakan yang dimakan oleh kepiting bakau pada setiap perlakuan dan ulangan. Data EPP diuji menggunakan ANOVA dengan taraf kepercayaan $\mathrm{P}>0,05$ dan menunjukan hasil bahwa pemberian pakan kombinasi tidak berpengaruh nyata pada tiap perlakuannya yaitu sebesar 26,1035,12\% (Gambar 5).

Efisiensi pemanfaatan pakan merupakan kemampuan suatu organisme dalam memanfaatkan pakan untuk kemudian digunakan untuk proses metabolisme dan pertumbuhan semaksimal mungkin. Efesiensi pemanfaatan pakan dapat dipengaruhi oleh kandungan nutrisi makro dari pakan yang digunakan. Berdasarkan hasil penelitian yang disajikan dalam diagram pada Gambar 5, diduga bahwa kandungan lemak yang tinggi pada pakan ikan rucah yaitu 1,49\% menyebabkan proses penyerapan bahan makanan lainnya menjadi tidak maksimal.

Yasin (2011) menyebutkan bahwa efisiensi pemanfaatan pakan akan meningkat jika kadar lemak dalam pakan berkurang. Ikan cenderung menyimpan lemak sebanyakbanyaknya terutama di dinding rongga saluran pencernaan. Bahan makanan yang masuk kedalam sistem pencernaan secara umum akan diolah menjadi molekul-molekul yang lebih sederhana. Hal ini bertujuan agar nutrisi bahan makanan dapat masuk kedalam sistem peredaran darah melalui sel-sel enterosit pada dinding usus.

Proses penyerapan bahan makanan tentu tidak akan maksimal jika dinding usus ditutupi oleh lemak yang berlebih, hal ini secara tidak langsung dapat mengganggu proses metabolisme secara umum dalam tubuh ikan menjadi tidak maksimal.

Metabolisme dalam tubuh yang terganggu akan menyebabkan proses fisiologis dalam tubuh tidak berjalan normal. Hal ini akan menyebabkan nafsu makan turun, jumlah pakan yang termakan sedikit, sumber energi yang masuk berkurang sehingga laju pertumbuhan spesifik dan pertumbuhan lebar karapas menjadi rendah

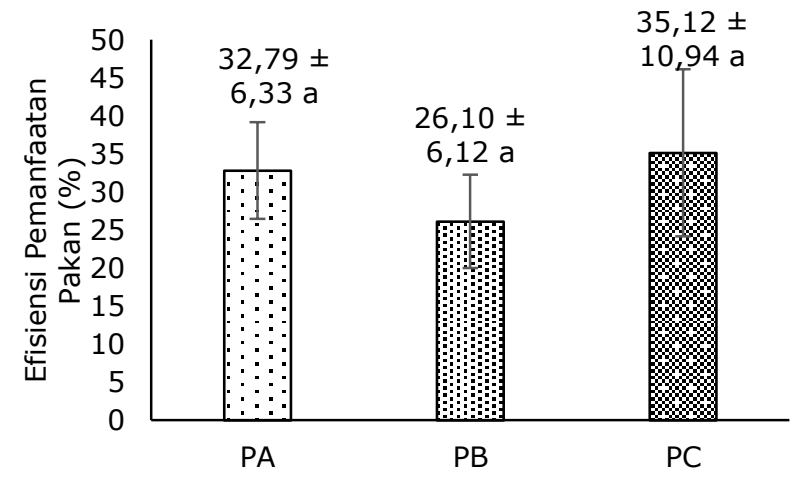

Keterangan : Huruf superscript yang sama menunjukkan pengaruh yang tidak berbeda nyata $(P>0,05)$

$\mathrm{PA}=$ pakan keong mas, $\mathrm{PB}=$ pakan kombinasi, $\mathrm{PC}=$ pakan ikan rucah

Gambar 5. Efisiensi Pemanfaatan Pakan Kepiting Bakau selama pemeliharaan 
Tabel 1. Data Kualitas Air Selama Pemeliharaan

\begin{tabular}{cccc}
\hline Parameter & Satuan & Kisaran & Referensi \\
\hline Suhu & ${ }^{\circ} \mathrm{C}$ & $28-31$ & $28-32$ (Cholik, 2005) \\
Salinitas & $\mathrm{ppt}$ & $21-24$ & $15-25$ (Ramelan,1994) \\
$\mathrm{pH}$ & - & $6,9-7,8$ & $7,3-8,5$ (Amir,1994) \\
DO & $\mathrm{mg} / \mathrm{l}$ & $3,58-4,88$ & $>3$ (Kuntiyo et al., 1994) \\
Amonia & $\mathrm{mg} / \mathrm{l}$ & $0,01-0,03$ & $<0,1$ (Kuntiyo et al.,1994) \\
\hline
\end{tabular}

(Karim, 2005). Menurut Subandiyono dan Hastuti (2010), protein yang berkualitas adalah protein yang memiliki kecernaan tinggi serta memiliki kandungan asam amino yang mirip dengan kandungan asam amino yang terdapat dalam tubuh kultivan.

Tingginya tingkat konsumsi pakan dengan rendahnya penggunaan energi untuk aktivitas tubuh akan meningkatkan persentase pemanfaatan pakan secara maksimal. Hal ini disebabkan oleh energi yang disimpan dalam tubuh terkonversi untuk pertumbuhan. Efesiensi pemanfaatan yang tinggi akan menggambarkan tingginya tingkat pertumbuhan, sebaliknya rendahnya pemanfaatan pakan menggambarkan rendahnya tingkat pertumbuhan. Hal ini didukung dengan pendapat Karim (2005) yang menyatakan bahwa semakin tinggi laju pertumbuhan maka semakin efesien pemanfaatan pakan yang dimakan oleh kultivan.

\section{KESIMPULAN}

Pemberian kombinasi pakan keong mas dan ikan rucah tidak memberikan berpengaruh yang nyata terhadap performa pertumbuhan dan derajat kelangsungan hidup kepiting bakau (Scylla sp.). Rata-rata nilai performa pertumbuhan dan derajat kelangsungan hidup kepiting bakau terbaik ditunjukkan pada pakan yang diberikan berupa ikan rucah, sedangkan terendah adalah kombinasi ikan rucah dan keong mas.

\section{REFERENSI}

Almada. D.P. 2001. Studi tentang waktu makan dan jenis umpan yang disukai kepiting bakau (Scylla serrata). [Skripsi]. Bogor: Fakultas Perikanan dan Ilmu Kelautan Institut Pertanian Bogor.

Amir. 1994. Penggemukan dan peneluran kepiting bakau. TECHner. Jakarta. Hal (41)

Arikuntoro. S. 2002. Prosedur Penelitian Suatu Pendekatan dan Praktek. Rineka Cipta. Jakarta.
Asyari dan Muflikhah, N. 2005. Pengaruh pemberian pakan tambahan ikan rucah berbeda terhadap pertumbuhan dan kelangsungan hidup ikan baung (Mystus nemurus C.V) dalam sangkar. Jurnal IImu Perairan dan Perikanan Indonesia, . 2 (2):107-112.

Effendie. 1997. Biologi Perikanan. Yayasan Pustaka Nusatama.Yogyakarta.

Hadadi. A. 2002. Pengaruh Kadar Karbohidrat Pakan Berebeda Terhadap Pertumbuhan dan Efisiensi Pakan Ikan Gurame (Osphronemus gouramy Lacepede) Ukuran 70 - 80 gr. [Tesis]. Sekolah Pasca Sarjana Institut Pertanian Bogor. Bogor.

Handajani, H dan Widodo, W. 2010. Nutrisi Ikan. Universitas Muhammadiyah Malang Press. Malang.

Hidayat, D., Dwi, S. dan Ade, Y. 2013. Kelangsungan hidup dan efesiensi pakan ika n gabus (Chana striata) yang diberi pakan berbahan baku tepung keong mas. Jurnal Akuakultur Rawa Indonesia. 1(2):161-172.

Huisman. E.A. 1987. The principles of fish culture production. Netherland: Departement of Aquaculture, Wageningen University.

Idha. A.A, Samidjan, I. dan Rachmawati, D.. 2013. Pemberian kombinasi pakan keong macan dan ikan rucah terhadap pertumbuhan dan kelulushidupan kepiting bakau (Scylla paramamosain). Jurnal Akuakultur. 2(4):131-138.

Ilyas, S., Cholik, F., Poernomo, A., Ismail, W., Rebegnatar, I.N.S., Arifudin, R., Koesoemadinata, S., Danakusumah, E. dan Partasasmita, S. 1987. Petunjuk teknis bagi pengoperasian unit usaha pembenihan (Hatchery) udang windu. Jakarta: Badan Penelitian dan Pengembangan Pertanian.

Karim, M.Y. 2005. Kinerja pertumbuhan kepiting bakau betina (Scylla serrata Forskal) pada berbagai salinitas media dan evaluasinya pada salinitas optimum dengan kadar protein pakan berbeda. 
[Disertasi]. Sekolah Pasca Sarjana. Institut Pertanian Bogor.

Karim, M.Y. 2008. Pengaruh salinitas terhadap metabolism kepiting bakau (Scylla olivacae). Jurnal Perikanan. 10(1):37-44.

Kasri, A. 1984. Pengaruh antibiotika dan makanan pada tingkat salinitas yang berbeda terhadap kelulushidupan dan perkembangan larva kepiting bakau (Scylla serrata). [Disertasi]. Sekolah Pasca Sarjana. Institut Pertanian Bogor.

Kuntiyo, Z.,A. dan Supratomo, T. 1994. Pedoman budidaya kepiting bakau (Scylla serrata) di tambak. Balai Budidaya Air Payau, Jepara.

Marwoto, R.M. 1997. Keong mas atau keong murbei (Pomacea spp.) di Indonesia. Prosiding Seminar Nasional Biologi. XV, 953-955. Lampung 24-26 Juli 1997.

Marzuqi, M., Suwirya, K. dan Tsumura, T. 1996. Pengaruh vitamin E terhadap perkembangan gonad udang windu (Penaeus monodon) asal tambak. Jurnal Penelitian Perikanan Indonesia. 2(2):15.

Moosa, M.K., Aswandy, L. dan Kasri, A. 1985. Kepiting bakau (Scylla serrata Forskal) di perairan Indonesia. LON-LIPI, Jakarta.

Ramelan, H.S. 1994. Pembenihan kepiting bakau (Scylla serrata). Direktorat Bina Pembenihan. Direktorat Jendral Perikanan. Jakarta. $79 \mathrm{HIm}$.

Sadinar, B., Samidjan, I. dan Rachmawati, D. 2013. Pengaruh perbedaan dosis paka nkeong mas dan ikan rucah pada kepiting bakau (Scylla paramamosain) terhadap pertumbuhan dan kelulushidupan dengan system battery di Tambak Tugu, Semarang. Journal of Aquaculture Management and Technology. 2(4):84-93.

Subandiyono dan Hastuti, S. 2010. Buku ajar nutrisi ikan. Lembaga Pengembangan dan Penjaminan Mutu Pendidikan Universitas Dipenogoro semarang. 233 hlm.

Sulaeman, Yamin, M., Parenrengi, A. dan Tenriulo, A. 2007. Pembesaran kepiting bakau di tambak. Laporan penelitian Tahun 2007. Balai Riset Budidaya Air Payau.

Suryabrata, S. 1983. Metode Penelitian. Rajawali. Jakarta.

Tacon, A.G.T. 1987. The nutrition and feeding farmed fish and shrimp. Training Manual FAO of The United Nations Brazilia, Brazil. 117 pp.

Warner, G.F. 1977. The Biologi of Crabs. Elek Science. London.

Winestri. J,D. Rachmawatidan, I. dan Samidjan. 2014. Pengaruh penambahan vitamin E pada pakan buatan terhadap pertumbuhan dan kelulushidupan kepiting bakau (Scylla paramamosain). Jurnal Akuakultur, 3(4):40-48.

Yasin, H. 2011. Pengaruh pemberian berbagai kadar karbohidrat dan lemak pakan ber-vitomolt terhadap efisiensi pakan dan pertumbuhan kepiting bakau (Scylla sp.). [Skripsi]. Universitas Hasanudin. Makasar. 